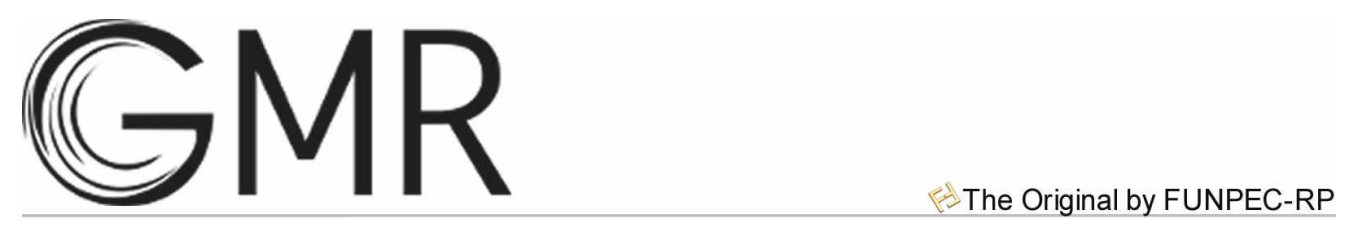

\title{
High temperature increases cooking time and seed darkening of common beans
}

\author{
R.L.M. Reis, D.A. Silva, J.G.R. Gonçalves, S.A.M. Carbonell and \\ A.F. Chiorato \\ Instituto Agronômico de Campinas, Campinas, SP, Brasil \\ Corresponding author: D.A. Silva \\ E-mail: daiagrouel2002@hotmail.com \\ Genet. Mol. Res. 20 (2): gmr18779 \\ Received December 04, 2020 \\ Accepted April 12, 2021 \\ Published April 30, 2021 \\ DOI http://dx.doi.org/10.4238/gmr18779
}

\begin{abstract}
High temperature is one of the main environmental factors that limit crop performance. It may also influence seed formation and quality. We compared the effect of high temperatures on seed darkening and cooking time of 12 genotypes of common beans. The experiments were sown in summer and in fall/winter growing seasons in three municipalities of São Paulo state (Campinas, Votuporanga, and Ribeirão Preto). A randomized block experimental design was adopted with four replications, analyzed in a $2 \times 3 \times 12$ factorial arrangement; the factors were two crop seasons, three locations and 12 genotypes. After harvest, the following seed traits were evaluated: cooking time soon after harvest $(\mathrm{CTH})$, after 30 days of storage (CT30), and after 60 days of storage (CT60); seed color soon after harvest (COLH), after 30 days of storage (COL30), and after 60 days of storage (COL60). Individual variance analyses were performed followed by average test and GGEbiplot interaction of factors analysis. Seed darkening was significantly affected by the crop season factor at all evaluation times, though there was no significant effect on cooking time. Significant effects on all variables were also found for location and genotypes. In the summer growing season, darker seeds were obtained, and among the locations, the seeds produced in Campinas were lighter in color. Increases in cooking time and in seed darkening were found with increases in storage time. The genotypes BRS Estilo, IAC Diplomata, Pérola, BRS Agreste, and IAC Imperador exhibited better seed quality (shorter cooking times and colors in the desired range ) at all locations in the summer season.
\end{abstract}


Key words: Phaseolus vulgaris; Technological quality; Cooking time; Seed darkening

\section{INTRODUCTION}

Dry beans are a food that symbolizes Brazilian gastronomy; they are recognized as an excellent protein source, with high caloric, mineral, vitamin, and crude fiber values that make them beneficial to consume. These beans, together with rice, form the basis of the daily diet of most Brazilians (Mesquita et al., 2007). As the dry bean plant is grown practically throughout Brazil, it is subject to a wide range of environmental conditions. High temperature is one of the main environmental factors that limit good crop performance (Custódio et al., 2009).

In the process of releasing, registering, and/or protecting a new cultivar, not only yield, tolerance to abiotic stresses, and disease resistance are important, but certain market demands as well. An important market demand that must be met is the quality of the bean seeds when the consumer acquires the product (Carbonell et al., 2003).

According to Carbonell et al. (2003), quality tests are required in the act of registering a new cultivar in the Brazilian Cultivar Protection Service (SNPC - Serviço Nacional de Proteção de Cultivares) - Ministry of Agriculture (MAPA - Ministério da Agricultura, Pecuária e Abastecimento) (Ordinance no. 294, of 14 October 1998 - Annex IV), which allow the registered cultivar to be introduced into the seed sale system in Brazil. Thus, technological and industrial evaluation are considered important within bean breeding programs, and are criteria for the selection of superior genotypes.

Hosfield et al. (1990) emphasized that the differences found in dry bean samples with regard to cooking time exhibit genetic and environmental components related to sowing time and the growing location, and, possibly, the interaction of these effects. Dalla Corte et al. (2003) affirm that in the effort to obtain seeds that have a shorter cooking time, factors such as high and low temperatures during the seed-filling phase, the growing conditions, post-harvest management (drying), and storage techniques are preponderant.

The dry bean is a product that quickly loses commercial value after harvest. During grain storage, the product itself deteriorates, and this deterioration is successive, irreversible, and cumulative, the speed of which depends on the environment, on the chemical components of the bean seeds themselves, and on the physical condition of the seeds at the beginning of storage. This loss of quality is mainly characterized by reductions in rehydration capacity, changes in flavor, seed coat darkening, and increases in the degree of seed hardness, which results in increased cooking time (Ribeiro et al., 2007).

Bean seeds have a wide range of colors; light color of the seed coat is preferred by Brazilian consumers through the belief that light-colored seeds show they are not so old and that they will cook more easily, and thus, they have higher commercial value. According to Bassinello et al. (2003), changes in the properties of color and cooking time of the seeds arise from effects of the environment and from chemical and/or enzymatic reactions in the seeds.

The determination of the seed coat color can be performed using colorimeter devices following the color standards of the CIE- Commission Internationale de I'Eclairage, that defined the most popular color space used to evaluate uniform colors the " $\mathrm{L} * \mathrm{a} * \mathrm{~b} *$ ", also known as CIELAB. This color space was created based on the opposite color theory, 
where $\mathrm{L}^{*}$ indicates the luminosity scale of 0 to 100 , ranging from black to white and, $\mathrm{a}^{*}$ and $\mathrm{b}^{*}$ are the chromatic coordinates. The colorimeter devices measure the reflected light at each wavelength or in specific bands, quantifying the spectral data to determine the color coordinates in the $\mathrm{L} * \mathrm{a} * \mathrm{~b} *$ color space, presenting the information in numerical terms (Konica, 2013).

Thus, "L" value is used to determine the brightness of the bean grains; that is, it determines the clarity of the tegument, being the most important value used for the commercialization of beans. In bean seeds of the carioca group (seed coat with beige background and brown stripes, known as pinto bean in the U.S.), light coloring of the seed coat is desirable, i.e., with an $\mathrm{L}$ value greater than 53 (Ribeiro et al., 2014). In relation to bean seeds of the black commercial group, the lower the $\mathrm{L}$ value, the darker the bean seed; $\mathrm{L}$ values within the range of 20 to 22 can be considered adequate.

In this context, the aim of this study was to compare how high temperatures most often reached in the summer season and in different locations influence seed quality of the common bean. Twelve genotypes were cultivated under natural growing conditions, in two crop seasons (summer and fall/winter) and in three locations with different climate zones of São Paulo State (Campinas, Votuporanga and Ribeirão Preto), evaluating the two main traits of technological quality required by the market; these being seed darkening and cooking time, to test our hypothesis that the high temperatures reached in the summer season and in the hottest locations negatively affects seed quality and it is also possible; to identify genotypes with the best grain quality under these conditions.

\section{MATERIAL AND METHODS}

The experiments were conducted in the field during two crop seasons, fall/winter of 2016 and summer of 2016-2017, at three locations: the Centro de Grãos e Fibras of the Instituto Agronômico - IAC, Fazenda Santa Elisa, Campinas, SP; the Polo Regional do Noroeste Paulista (Centro de Seringueira e Sistemas Agroflorestais), in Votuporanga, SP; and the Polo Regional do Centro Leste (Centro de Cana), in Ribeirão Preto, SP. The choice of the municipalities was based on their belonging to different climate zones, with median to hot temperatures, both in the winter and summer months.

Twelve dry bean cultivars were used (Table 1). They presented different colors of tegument and different growth habits as I, II and III (upright determinate, indeterminate and prostrate indeterminate) and, have been chosen considering their known performance for water deficit tolerance in regions where high temperatures occur, such as in the Northern part of the State of São Paulo and in the Center-West of Brazil. In addition, these genotypes were previously evaluated for agronomic traits under these conditions (Silva et al., 2018), and also evaluated regarding the reproductive biology at high temperatures under controlled conditions (Silva et al., 2020).

The experimental design adopted was randomized blocks with four replications, analyzed in a $2 \times 3 \times 12$ factorial arrangement, i.e. as factors were considered, the two crop season, the three locations and 12 genotypes. Each experimental plot consisted of four 4meter rows, with a population of 10 plants per meter and $0.5 \mathrm{~m}$ spacing between rows. All experimental areas were irrigated in the absence of rainfall with the use of sprinklers; soil moisture was kept at $-40 \mathrm{kPa} / \mathrm{centibars,} \mathrm{according} \mathrm{to} \mathrm{the} \mathrm{technical} \mathrm{recommendation} \mathrm{inserted}$ 
in the manual of the Watermark ${ }^{\circledR}$ tensiometer meter. Crop treatments were carried out according to crop needs.

Table 1. Twelve genotypes of common dry bean used in the study of tolerance to high temperature in three locations during two crop seasons under controlled conditions.

\begin{tabular}{llll}
\hline \multicolumn{1}{c}{ Genotypes } & Type of bean seed & Growth Habit & Origin $^{1 /}$ \\
\hline 1-SEA 5 & Cream & Type I & CIAT \\
2-IAC Imperador & Carioca & Type I & IAC \\
3-SER 16 & Red & Type I & CIAT \\
4- Pérola & Carioca & Type III & EMBRAPA \\
5-IAC Milênio & Carioca & Type III & IAC \\
6-FT Nobre & Black & Type II & FT-SEMENTES \\
7-BRS Estilo & Carioca & Type II & EMBRAPA \\
8-IAPAR 81 & Carioca & Type II & IAPAR \\
9- IAC Diplomata & Black & Type II & IAC \\
10- IPR Tangará & Carioca & Type II & IAPAR \\
11- BRS Agreste & Brown & Type II & EMBRAPA \\
12- IAC Sintonia & Carioca & Type II & IAC \\
\hline "IAT CInternational Center for Tropical Agriculture; IAC = Instituto Agronômico - IAC; EMBRAPA = Empresa Brasileira de Pesquisa
\end{tabular}

Agropecuária; FT-SEMENTES = Força Total Sementes; IAPAR = Instituto Agronômico do Paraná.

After harvest, the following analyses were made:

Seed darkening: obtained by reading the lightness $\left(\mathrm{L}^{*}\right)$ of the seed coat, evaluated in a sample of approximately $200 \mathrm{~g}$ from the trials of fall/winter 2016 and summer 2016/2017 from the three locations - Campinas, Votuporanga, and Ribeirão Preto. Readings were made soon after seed harvest (COLH), at 30 days of storage (COL30), and 60 days of storage (COL60) using the Minolta ${ }^{\circledR}$ model CR-410 colorimeter device, $\mathrm{D}_{65}$ standard illuminant and $2^{\circ}$ standard observer. Due to the typical bicolor character of the seed coats of the carioca group bean seeds, 10 repetitions were made for each plot. The samples used for analysis soon after harvest were kept in plastic bags and placed on shelving with ambient temperature and lighting for evaluation of the seeds by sampling at 30 and 60 days of storage. During the storage period, the seeds were periodically turned over so as to receive light in a homogenous manner.

Bean seed cooking time: three $30 \mathrm{~g}$ samples of whole, uniform bean seeds from each plot were used. One of the samples was used to measure cooking time soon after seed harvest (CTH), and the other two samples were stored in paper bags and kept on a shelf in a room with ambient lighting and temperature in the municipality of Campinas, SP, for determination of bean seed cooking time after 30 days of storage (CT30) and 60 days of storage (CT60). The method used for determination of cooking time was proposed by Proctor and Watts (1987), in which $30 \mathrm{~g}$ of bean seeds were placed to soak in distilled water at ambient temperature for $16 \mathrm{~h}$. After this period, twenty-five bean seeds were sampled and placed individually in the holes in the base of the Mattson cooker, with each grain remaining under a $90 \mathrm{~g}$ metal rod with a $1.48 \mathrm{~mm}$ tip diameter. After being properly assembled, the cooker was placed inside a beaker of $3000 \mathrm{~mL}$ of capacity containing 1000 $\mathrm{mL}$ of boiling distilled water, and placed on a hot plate. The cooking time was timed in minutes until thirteen grains were completely drilled through the rods of the appliance.

The results obtained were subjected to combined analysis of variance in a triple factorial arrangement $(2 \times 3 \times 12)$, with the first factor constituted by the two crop seasons, the second factor by the three locations, and the third factor by the twelve genotypes with 
four field repetitions, considering the effect of all the factors as fixed. After that, the mean values of the genotypes were compared by the Scott-Knott test at 5\% probability, and GGEBiplot analysis was performed with GGEBiplotGui R-package to detect the best genotypes in each location for each variable as recommended by Yan et al. (2020) in their cultivar and environment evaluation based in GGE-biplot.

The climate data regarding maximum and minimum temperatures and rain accumulated during crop development in the different locations and crop seasons were taken from CIIAGRO online - Centro Integrado de Informações Agrometeorológicas, and they are shown in Figure 1.

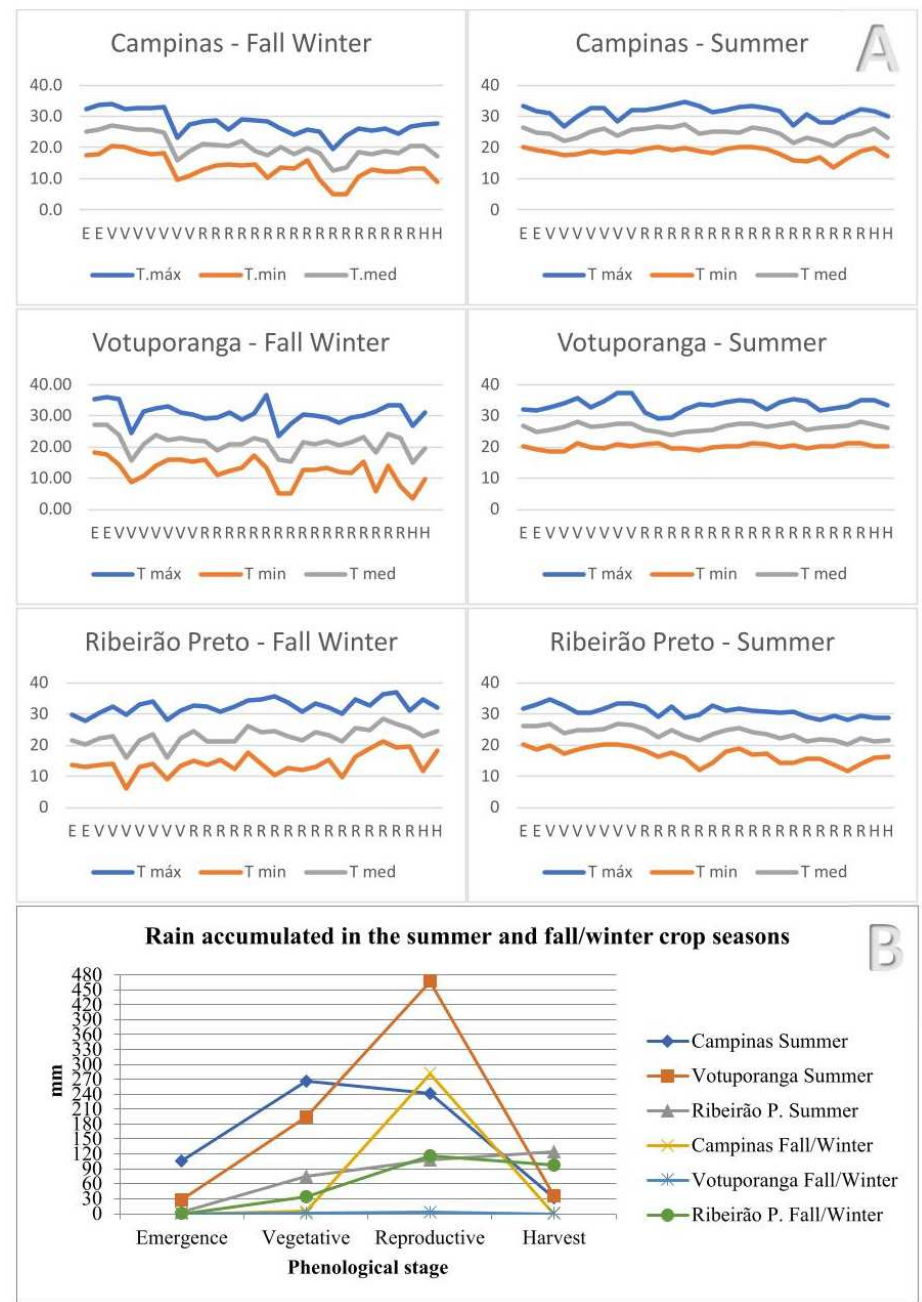

Figure 1. Climate data during the crop cycle. A. Mean value of the maximum, minimum and medium temperatures in the municipalities of Campinas, SP, Votuporanga, SP, and Ribeirão Preto, SP, in the fall/winter 2016 and summer 2016/2017 crop seasons. Phenologicals stages durng cultvaton: E (emergence), V (vegetative), $\mathbf{R}$ (reproductive), $\mathbf{H}$ (harvest) B. Rain accumulated in the municipalities of Campinas, SP, Votuporanga, SP, and Ribeirão Preto, SP, in the fall/winter 2016 and summer 2016/2017 crop seasons. 


\section{RESULTS AND DISCUSSION}

A significant effect of the crop season factor was observed by analysis of variance only for the variables COLH, COL30, and COL60. An effect of the crop season, as result from an increase in mean maximum temperature in the summer experiments, was the increase of seed darkening in all evaluation times. The sources of variation of location, genotype, crop season $\mathrm{x}$ genotype interaction, location $\mathrm{x}$ genotype interaction, and crop season $\mathrm{x}$ location $\mathrm{x}$ genotype triple interaction were significant for all the variables studied, showing the differentiated behavior of the genotypes in the crop seasons and in the locations (Table 2). The coefficients of environmental variation were from low to medium magnitude, ranging from $2.72 \%$ for $\mathrm{COLH}$ to $16.89 \%$ for CT30, suggesting good experimental accuracy (Table 2).

Table 2. Summary of analyses of variance of six variables: bean seed cooking time at harvest (CTH), after 30 days of storage (CT30), (CT60); color of bean seeds at harvest (COLH) and color of bean seeds after 30 days of storage (COL30) and after 60 days of storage (COL60) regarding 12 common dry bean genotypes sown in the fall/winter 2016 and summer 2016/2017 crop seasons in the municipalities of Campinas, SP, Votuporanga, SP, and Ribeirão Preto, SP.

\begin{tabular}{|c|c|c|c|c|c|c|c|}
\hline \multirow{3}{*}{ Sources of Variation } & \multirow{3}{*}{ DF } & \multicolumn{6}{|c|}{ Mean Squares (MS) } \\
\hline & & CTH & CT30 & CT60 & COLH & COL30 & COL60 \\
\hline & & minutes & minutes & minutes & $\mathbf{L}$ & $\mathbf{L}$ & $\mathbf{L}$ \\
\hline Crop Season (CS) & 1 & 28.60 & 7.50 & 1.00 & $183.00 * *$ & $233.00^{* * *}$ & $159.00^{* *}$ \\
\hline Location $(\mathrm{L})$ & 2 & $863.70^{* *}$ & $1074.60^{* *}$ & $1102.00 * *$ & $477.00 * *$ & $737.00 * *$ & $928.70^{* *}$ \\
\hline Genotype (G) & 11 & $506.00^{* * *}$ & $506.40^{* *}$ & $664.00^{* *}$ & $4281.00^{* *}$ & $3548.00 * *$ & $3095.10 * *$ \\
\hline L x Block & 9 & $64.40 * *$ & 37.70 & 57.00 & 2.00 & 3.00 & $4.00^{*}$ \\
\hline CS $x$ L & 2 & $2280.70 * *$ & $2238.90^{* *}$ & $4007.00 * *$ & $33.00 * *$ & $18.00 * *$ & 3.80 \\
\hline $\mathrm{CS} \times \mathrm{G}$ & 11 & $100.40^{* * *}$ & $78.80^{* *}$ & $213.00^{* *}$ & $15.00^{* * *}$ & $20.00 * *$ & $17.30^{* *}$ \\
\hline$L \times G$ & 22 & $152.50 * *$ & $189.20 * *$ & $199.00 * *$ & $20.00 * *$ & $28.00 * *$ & $35.30 * *$ \\
\hline $\mathrm{CS} \times \mathrm{L} \times \mathrm{G}$ & 22 & $189.90 * *$ & $235.40 * *$ & $331.00 * *$ & $8.00 * *$ & $8.00^{* *}$ & $6.70 * *$ \\
\hline Error & 207 & 24.30 & 28.00 & 40.00 & 2.00 & 2.00 & 1.80 \\
\hline $\mathrm{W}$ & & 0.97906 & 0.96223 & 0.98152 & 0.9124 & 0.94197 & 0.94375 \\
\hline p-value & & 0.00031 & $7.909^{-0 /}$ & 0.00088 & $6.373^{-12}$ & $3.184^{-109}$ & $4.92^{-09}$ \\
\hline $\mathrm{CV}(\%)$ & & 15.61 & 15.20 & 16.89 & 2.72 & 3.00 & 3.12 \\
\hline
\end{tabular}

\section{Cooking time}

For the bean seed cooking time, there were no significant effects of the crop season factor at harvest or after the periods of storage (30 and 60 days after harvest), i.e., the higher temperatures reached in the summer crop season did not result in "seed coat hardening" that would lead to an expected longer cooking time. However, a significant effect was seen for the crop season $\mathrm{x}$ genotype interaction, which shows differentiated behavior of the genotypes in the face of the crop seasons, and the consequences of these effects were later observed. According to Dalla Corte et al. (2003), cooking time is controlled genetically and is affected by various environmental factors. Among them are climate factors, growing conditions, soil fertility, and post-harvest processing. Bertoldo et al. (2009) identified that bean seed cooking time is affected by environmental and/or physiological factors, such as seed storage conditions and time, and the effect of the genotype $\mathrm{x}$ environment interaction. 
In agreement with these authors, a significant effect was observed on bean seed cooking time when the seeds were grown in different locations (Table 2).

The Scott-Knott means comparison test shows that Campinas was the location that had the lowest cooking time, both at harvest and at 30 and 60 days of storage, with times of 28.34, 30.97, and 33.89 minutes, respectively (Table 3). According to Rodrigues et al. (2005), the cooking time less of 30 minutes is considered ideal for common dry beans because it means energy and capital savings. For bean seed cooking time soon after harvest, Votuporanga was the location that exhibited the longest time, with a mean value of 34.25 minutes.

Table 3. Means comparison test (Scott-Knott at $5 \%$ probability) regarding eight traits of the common dry bean crop: bean seed cooking time at harvest (CTH) and after 30 days of storage (CT30) and 60 days of storage (CT60), and color of the bean seeds at harvest (COLH) and after 30 days of storage (COL30) and 60 days of storage (COL60), in relation to growing of 12 genotypes sown in fall/winter 2016 and in summer 2016/2017 in the municipalities of Campinas, SP, Votuporanga, SP, and Ribeirão Preto, SP.

\begin{tabular}{|c|c|c|c|c|c|c|c|c|c|c|c|c|}
\hline & CTH & & CT30 & & CT60 & & COLH & & COL30 & & COL60 & \\
\hline Crop Season & minutes & & minutes & & minutes & & $\mathbf{L}$ & & $\mathbf{L}$ & & $\mathbf{L}$ & \\
\hline 1-Fall/Winter & 31.91 & $\mathrm{a}$ & 34.66 & $\mathrm{a}$ & 37.63 & $\mathrm{a}$ & 46.54 & $\mathrm{a}$ & 44.84 & $\mathrm{a}$ & 43.39 & $\mathrm{a}$ \\
\hline 2-Summer & 31.28 & $\mathrm{a}$ & 34.99 & $\mathrm{a}$ & 37.54 & $\mathrm{a}$ & 44.95 & $\mathrm{~b}$ & 43.04 & $\mathrm{~b}$ & 41.90 & $\mathrm{~b}$ \\
\hline \multicolumn{13}{|l|}{ Location } \\
\hline 1-Campinas & 28.34 & $\mathrm{c}$ & 30.97 & $\mathrm{~b}$ & 33.89 & $\mathrm{c}$ & 47.68 & $\mathrm{a}$ & 46.26 & $\mathrm{a}$ & 44.94 & $\mathrm{a}$ \\
\hline 2-Votuporanga & 34.25 & $\mathrm{a}$ & 36.54 & $\mathrm{a}$ & 38.31 & $\mathrm{~b}$ & 46.25 & $\mathrm{~b}$ & 44.69 & $\mathrm{~b}$ & 43.89 & $\mathrm{~b}$ \\
\hline 3-Ribeirão Preto & 32.18 & $\mathrm{~b}$ & 36.96 & $\mathrm{a}$ & 40.55 & $\mathrm{a}$ & 43.31 & $\mathrm{c}$ & 40.87 & $\mathrm{c}$ & 39.11 & $\mathrm{c}$ \\
\hline \multicolumn{13}{|l|}{ Genotype } \\
\hline 1-SEA 5 & 43.62 & $\mathrm{a}$ & 46.79 & $\mathrm{a}$ & 51.99 & $\mathrm{a}$ & 53.1 & $\mathrm{~b}$ & 50.22 & $\mathrm{c}$ & 48.29 & $\mathrm{c}$ \\
\hline 2-IAC Imperador & 36.82 & $\mathrm{~b}$ & 40.06 & $\mathrm{~b}$ & 41.42 & $\mathrm{~b}$ & 53.41 & $\mathrm{~b}$ & 51.00 & $\mathrm{~b}$ & 49.38 & $\mathrm{~b}$ \\
\hline 3-SER16 & 29.92 & $\mathrm{c}$ & 33.58 & $\mathrm{c}$ & 36.49 & $\mathrm{c}$ & 25.01 & d & 25.00 & e & 24.95 & $\mathrm{e}$ \\
\hline 4- Pérola & 29.54 & $\mathrm{c}$ & 34.97 & $\mathrm{c}$ & 36.24 & c & 51.13 & $\mathrm{c}$ & 49.06 & $\mathrm{~d}$ & 47.49 & d \\
\hline 5-IAC Milênio & 31.52 & $\mathrm{c}$ & 34.61 & $\mathrm{c}$ & 38.42 & $\mathrm{~b}$ & 53.13 & $\mathrm{~b}$ & 50.58 & $\mathrm{c}$ & 48.65 & $\mathrm{c}$ \\
\hline 6-FT Nobre & 28.57 & d & 32.13 & d & 34.21 & c & 22.67 & $\mathrm{e}$ & 22.99 & $\mathrm{f}$ & 23.07 & $\mathrm{f}$ \\
\hline 7-BRS Estilo & 26.28 & $\mathrm{~d}$ & 30.57 & $\mathrm{~d}$ & 32.39 & $\mathrm{c}$ & 53.30 & $\mathrm{~b}$ & 50.85 & $\mathrm{~b}$ & 49.18 & $\mathrm{~b}$ \\
\hline 8-IAPAR 81 & 30.04 & $\mathrm{c}$ & 32.98 & $\mathrm{c}$ & 35.49 & c & 53.14 & $\mathrm{~b}$ & 50.36 & $\mathrm{c}$ & 48.81 & $\mathrm{c}$ \\
\hline 9-IAC Diplomata & 28.89 & d & 29.65 & d & 32.59 & c & 23.28 & $\mathrm{e}$ & 23.50 & $\mathrm{f}$ & 23.59 & f \\
\hline 10-IPR Tangará & 30.56 & $\mathrm{c}$ & 32.85 & $\mathrm{c}$ & 35.03 & $\mathrm{c}$ & 53.19 & $\mathrm{~b}$ & 51.05 & $\mathrm{~b}$ & 49.70 & $\mathrm{~b}$ \\
\hline 11-BRS Agreste & 30.12 & $\mathrm{c}$ & 34.38 & $\mathrm{c}$ & 37.12 & $\mathrm{c}$ & 54.62 & a & 52.27 & $\mathrm{a}$ & 50.64 & a \\
\hline 12-IAC Sintonia & 33.21 & c & 35.30 & $\mathrm{c}$ & 39.62 & $\mathrm{~b}$ & 52.96 & $\mathrm{~b}$ & 50.42 & c & 47.98 & d \\
\hline
\end{tabular}

$\mathrm{L}=$ Lightness. Crop Season $=$ mean value of each crop season considering the three growing locations (Campinas, SP, Votuporanga, SP, and Ribeirão Preto, SP); Location = mean of each location considering the two crop seasons (fall/winter 2016 and summer 2016/2017); Genotypes = mean of each genotype considering the six environments (summer 2016 and fall/winter 2016/2017 crop seasons in the municipalities of Campinas, SP, Votuporanga, SP, and Ribeirão Preto, SP).

For the period of 30 days of storage, the environments of Votuporanga and Ribeirão Preto did not significantly differ from each other, and exhibited the longest times, 36.54 and 36.96 minutes, respectively. After 60 days of storage, the longest cooking time was 40.55 minutes, for Ribeirão Preto (Table 3). According to Sgarbieri (1987), losses in dry bean quality affecting cooking time during seed storage are found because of development of "hardshell", such that seeds do not absorb enough water and do not soften during cooking, and by loss of cotyledon cooking properties, i.e., "hard-to-cook", in which seeds absorb enough water but cooking time does not decrease. Hohlberg and Stanley (1987) add that prolonged cooking time is directly related to these two processes.

The environment of Ribeirão Preto in the fall/winter reached the highest mean maximum temperature $\left(32.3^{\circ} \mathrm{C}\right)$ and the highest mean minimum temperature $\left(14.3^{\circ} \mathrm{C}\right)$ 
among the locations (Figure 1), and the longest cooking times were from this environment in the three evaluations, with mean values of 38.12 minutes for $\mathrm{CTH}, 42.23$ minutes for CT30, and 47.28 minutes for CT60. In the summer crop season, Ribeirão Preto had the lowest mean maximum temperature $\left(30.8^{\circ} \mathrm{C}\right)$ and minimum temperature $\left(16.7^{\circ} \mathrm{C}\right)$ in relation to the other locations in the summer (Figure 1), and the shortest cooking times were identified, with 26.24, 31.69, and 33.82 minutes for CTH, CT30, and CT60, respectively.

In the fall/winter crop season, the municipality of Campinas had mild temperatures (mean maximum temperature of $27.9^{\circ} \mathrm{C}$ and mean minimum of $13.3^{\circ} \mathrm{C}$ ), and cooking time of 25.72 minutes for $\mathrm{CTH}, 27.00$ minutes for CT30, and 27.73 minutes for CT60. For the CTH and CT30 traits, the genotypes were separated statistically into four different classes (Table 3). For CTH, the genotypes BRS Estilo, FT Nobre, and IAC Diplomata (7, 6, and 9) constituted the group of lowest cooking time, with values of 26.28, 28.57, and 28.89 minutes, respectively. For CT30, once more the genotypes BRS Estilo, FT Nobre, and IAC Diplomata (7, 6, and 9) had the shortest cooking times, with values of $30.57,32.13$, and 29.65 minutes, respectively. For CT60, cooking time ranged from 32.39 to 51.99 minutes (Table 3), in which SER 16, Pérola, FT Nobre, BRS Estilo, IAPAR 81, IAC Diplomata, IPR Tangará, and BRS Agreste (3, 4, 6, 7, 8, 9, 10, and 11) had cooking time shorter than 37.12 minutes. The genotype SEA 5 (1) had the longest cooking time in both evaluation times, at 43.62 minutes for CTH, 46.79 minutes for CT30, and 51.99 minutes for CT60 (Table 3).

From the mean values of cooking time observed in Table 3, a gradual increase can be observed in mean cooking time for all the genotypes and locations over the time of bean seed storage. The results are in agreement with Bertoldo et al. (2009) who found an influence of storage time on cooking time of the dry bean cultivars, which resulted in an increase in cooking time of bean seeds over the days of storage. Similar results were found by Morais et al. (2010), who evaluated the cooking time of the cultivars BRS Supremo and Pérola in five storage periods and also observed that the cooking time of the bean seeds increased along with time of storage under ambient temperature conditions, with similar behavior for the carioca and black bean groups.

The GGE-Biplot graphs for cooking time are shown in Figures 2, 3, and 4 to identify the genotypes with the shortest cooking times for each environment. It should be noted that, in this case, lower values are desirable because they indicate short cooking time and, thus, observation of the results should be made in an inverted manner because the highest values are not assigned to the best genotypes.

With regard to cooking time of bean seeds after harvest, the formation of two sectors of correlation among the environments is observed. The environments of Votuporanga in the summer, Ribeirão Preto in the summer, Campinas in the fall/winter, and Votuporanga in the fall/winter (CTHSV, CTHSRP, CTHWC, and CTHWV, respectively) proved to be correlated, with the genotype SEA 5 (1) as vertex, the genotype of longest cooking time for these environments. The genotypes Pérola, BRS Estilo, and IAC Diplomata (4, 7, and 9) had the shortest cooking time, as they are on the vertex opposite the genotype SEA 5. The environment of Ribeirão Preto in the fall/winter (CTHWRP) had larger discrepancy in relation to the others, but even so, it was correlated with the environment of Campinas in the summer (CTHSC), where, in this case, the genotype BRS Estilo (7) achieved the shortest cooking time for these environments (CTHWRP and CTHSC) (Figure 2). 


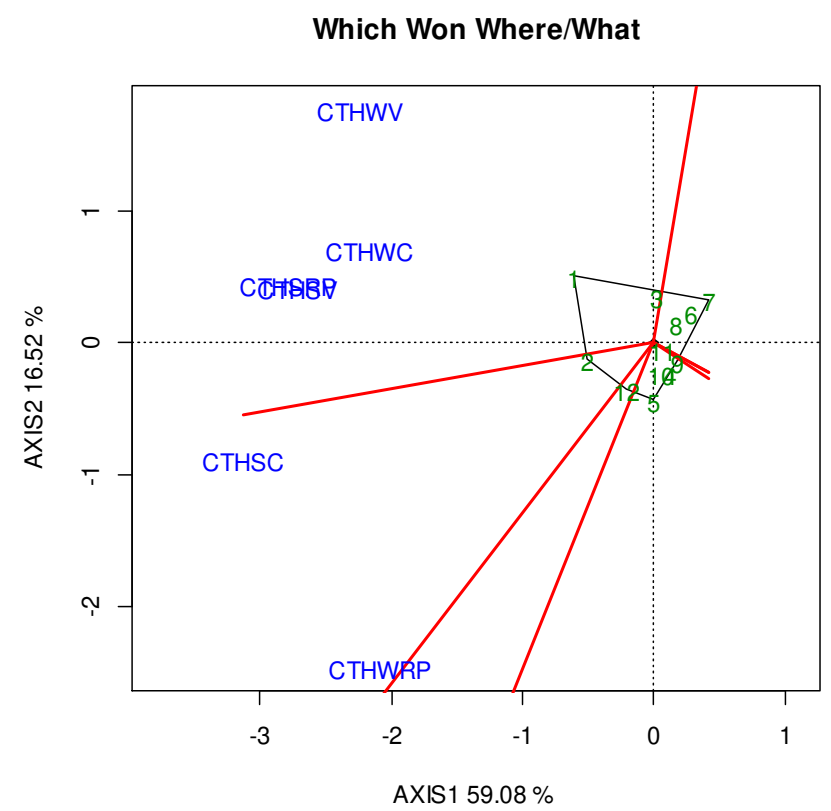

Figure 2. GGE-Biplot ("which won where") for the data of cooking time after harvest of bean seeds (minutes) of twelve genotypes of common dry bean; CTHWC = cooking time at harvest in Campinas in the fall/winter; CTHWV = cooking time at harvest in Votuporanga in the fall/winter; CTHWRP $=$ cooking time at harvest in Ribeirão Preto in the fall/winter; CTHSC = cooking time at harvest in Campinas in the summer; CTHSV = cooking time at harvest in Votuporanga in the summer; and CTHSRP = cooking time at harvest in Ribeirão Preto in the summer. Genotypes = 1-SEA5, 2-IAC Imperador, 3-SER 16, 4- Pérola, 5-IAC Milênio, 6-FT Nobre, 7BRS Estilo, 8-IAPAR 81, 9-IAC Diplomata, 10-IPR Tangará, 11-BRS Agreste, and 12-IAC Sintonia.

In relation to cooking time after 30 days of storage, Figure 3 shows correlations between the environments of Ribeirão Preto in the fall/winter and Ribeirão Preto in the summer (CT30WRP and CT30SRP), in which the genotype IAC Diplomata (9) had the shortest cooking time and the genotype IAC Imperador (2) had the worst cooking time for this group of environments. The other environments, Campinas in the summer, Campinas in the fall/winter, Votuporanga in the fall/winter, and Votuporanga in the summer (CT30SC, CT30WC, CT30WV, and CT30SV) were also correlated, and in this group of environments, the genotype BRS Estilo (7) had the shortest cooking time, being in the vertex opposed to the genotype SEA 5 (1), which had the worst performance for this characteristic in this group of environments (Figure 3).

With regard to cooking time at 60 days of storage, Figure 4 shows the formation of three sectors of correlation for the environments studied, in which the first sector is constituted by Votuporanga in the fall/winter, Campinas in the summer, and Campinas in the fall/winter (CT60WV, CT60SC, and CT60WC); the genotype IAC Diplomata (9) had the shortest cooking time in these locations, and SEA 5 had the worst time. The second factor, constituted by the environments of Ribeirão Preto in the fall/winter and Ribeirão Preto in the summer (CT60WRP and CT60SRP) showed the genotype BRS Estilo (7) with the shortest cooking time, and the genotype IAC Imperador (2), on the opposite side of the polygon, with the longest cooking time for the environments of this sector. The third sector is constituted by the environment of Votuporanga in the summer (CT60SV), the environment with the most stressful temperatures; the genotype BRS Estilo (7) had the best cooking time for these conditions; and the genotype IAC Sintonia (12) had the longest cooking time at 60 days (Figure 4). 


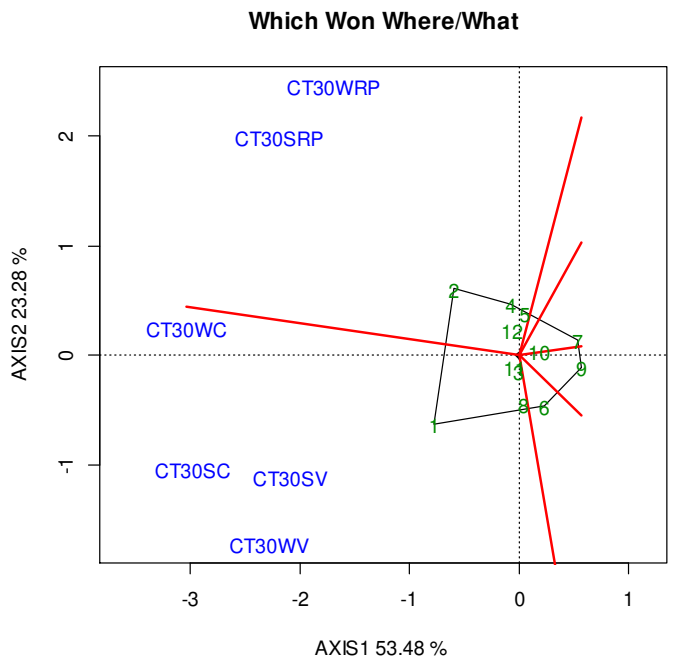

Figure 3. GGE-Biplot ("which won where") for the data of cooking time after 30 days of storage (minutes) of 12 genotypes of common dry bean; CT30WC $=$ cooking time after 30 days in Campinas in the fall/winter; CT30WV $=$ cooking time after 30 days in Votuporanga in the fall/winter; CT30WRP = cooking time after 30 days in Ribeirão Preto in the fall/winter; CT30SC = cooking time after 30 days in Campinas in the summer; CT30SV = cooking time after 30 days in Votuporanga in the summer; and CT30SRP = cooking time after 30 days in Ribeirão Preto in the summer. Genotypes = 1-SEA5, 2-IAC Imperador, 3-SER 16, 4- Pérola, 5-IAC Milênio, 6FT Nobre, 7-BRS Estilo, 8-IAPAR 81, 9-IAC Diplomata, 10-IPR Tangará, 11-BRS Agreste, and 12-IAC Sintonia.

Which Won Where/What

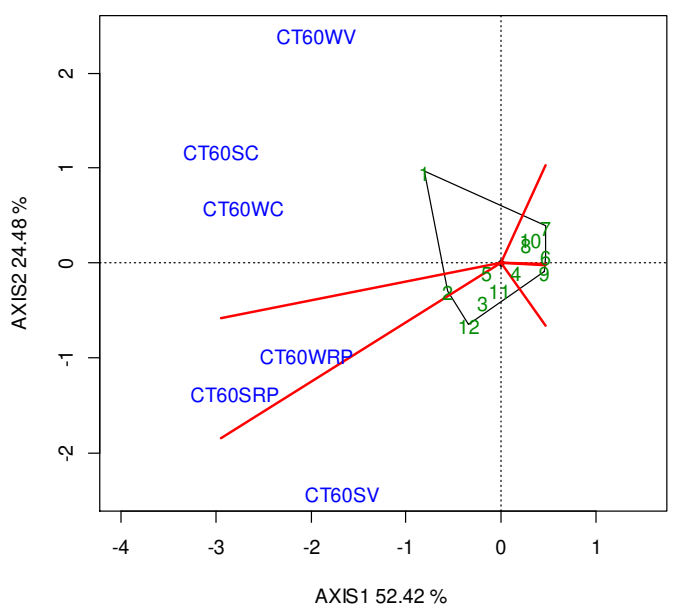

Figure 4. GGE-Biplot ("which won where") for the data of cooking time after 60 days of storage (minutes) of 12 genotypes of common dry bean; CT60WC = cooking time after 60 days in Campinas in the fall/winter; CT60WV $=$ cooking time after 60 days in Votuporanga in the fall/winter; CT60WRP $=$ cooking time after 60 days in Ribeirão Preto in the fall/winter; CT60SC = cooking time after 60 days in Campinas in the summer; CT60SV = cooking time after 60 days in Votuporanga in the summer; and CT60SRP = cooking time after 60 days in Ribeirão Preto in the summer. Genotypes = 1-SEA5, 2-IAC Imperador, 3-SER 16, 4- Pérola, 5-IAC Milênio, 6FT Nobre, 7-BRS Estilo, 8-IAPAR 81, 9-IAC Diplomata, 10-IPR Tangará, 11-BRS Agreste, and 12-IAC Sintonia. 


\section{Bean seed darkening}

For seed coat color, there was an effect of the factors of crop season, location, and genotype and of the interactions of these factors (Table 2). Cargnelutti Filho et al. (2006) and Junk-Knievel et al. (2007) identified genotype by environment interaction for bean seed darkening, which, according to the latter author, can be attributed to the sensitivity of the genotypes to the environmental variations for the trait, such as differences in the time of harvest and variability of light, temperature, and moisture.

By the Scott-Knott means test at 5\% probability, it was found that in the fall/winter crop season, in which rainfall at harvest time is less frequent, with $268.1 \mathrm{~mm}$ of rain accumulated for Campinas, $4.2 \mathrm{~mm}$ for Votuporanga, and $249.3 \mathrm{~mm}$ for Ribeirão Preto, lighter-colored bean seeds were grown, i.e., bean seeds with higher mean values for lightness in the three evaluation times (COLH, COL30, and COL60), with mean values of 46.54 L for COLH, 44.84 L for COL30, and 43.39 L for COL60 (Table 3).

In the summer, the carioca and cream bean seeds were darker than the bean seeds harvested in the fall/winter, with mean lightness values of 44.95, 43.04, and $41.90 \mathrm{~L}$ for COLH, COL30, and COL60, respectively (Table 3), and also with $644.8 \mathrm{~mm}$ of rain accumulated for Campinas, $723.7 \mathrm{~mm}$ for Votuporanga, and $309.2 \mathrm{~mm}$ for Ribeirão Preto.

For both crop seasons, gradual darkening of the seed coat was observed over time in storage of the bean seeds, i.e., loss in L. value (Table 3). According to Bassinello et al. (2003) and Rios et al. (2002), after storage, the darker color of the seed coat may be a consequence of the effects of environment and of chemical and/or enzymatic reactions in the bean seeds, such as increase in the activity of the enzyme polyphenol oxidase, associated with activity of the enzyme peroxidase and with increase in the content of phenolic compounds.

The highest mean lightness of bean seeds, i.e., the most light-colored bean seeds in all evaluation times, was in Campinas; COLH, COL30, and COL60, had values of 47.68, 46.26, and 44.94 L, respectively. Campinas had a mean temperature considered ideal for the crop during the experiments of summer and fall/winter, as well as the absence of rainfall during the fall/winter harvest and low rainfall during the summer harvest (Figure 1). According to Scholz and Fonseca Junior (1999), the characteristics of the seed coat, such as cooking time and seed color, may be affected by other factors besides high temperature, as for example, rain at harvest and diseases at the end of the crop cycle. This is confirmed upon observing that the conditions in Ribeirão Preto, though not the location with the highest temperature but rather the highest rainfall in the harvest period (Figure 1), led to darker bean seeds in the combined mean value (Table 3) both for COLH and for COL30 and COL60, with lightness values of 43.31, 40.87, and $39.11 \mathrm{~L}$, respectively.

It is noteworthy that at the time at which the plants reached the seed-filling developmental stage (R8) in Ribeirão Preto in both crop seasons, there were rains up to the stage of physiological maturity, with 187.7 millimeters accumulated for fall/winter and 146.2 millimeters for the summer, a fact that may have contributed to greater darkening of the seeds in that location. Results similar to those we obtained were described by Ribeiro et al. (2004), who evaluated the effects of the genotype x environment interaction on coloring of bean seeds over two years in two crop seasons (rainy and dry). These authors found that the excess of moisture, especially during the period of seed filling, contributed to greater darkening of the seed coat in cultivars of the carioca group, which is not desirable. 
Carbonell et al. (2003), in a study performed in twelve environments, also identified the effect of the soil and climate conditions of the environments on the technological quality of bean seeds.

The genotypes studied showed significant differences in regard to the variable COLH; and by the means test of Tukey ( $>0.05$ ), the genotype BRS Agreste, that has a brown-colored bean seed, without streaks, had the lightest-colored seed coat. The only genotype of the carioca type seed coat to exhibit lower lightness (darker seed coat) was Pérola, with $51.13 \mathrm{~L}$; the others with this type of seed coat had mean values from 53.41 to $52.96 \mathrm{~L}$, lightness values considered satisfactory by the consumer market. As expected, the genotypes with black seed coat, FT Nobre (22.67 L) and IAC Diplomata (23.28 L), were clustered in the last group, i.e., the darkest bean seeds for all the variables of lightness (Table 3).

In the evaluations COL30 and COL60, the genotypes differed statistically by the combined Scott Knott test at 5\% probability. The genotype with greatest lightness was the cultivar BRS Agreste, with a brown seed coat. For the carioca type bean, the lightestcolored seed coat was obtained by the cultivars IAC Imperador, BRS Estilo, and IPR Tangará. It should be noted that all the genotypes with carioca and brown seed coat exhibited seed darkening with the increase in storage time. The genotype SER 16, which has a red seed coat, exhibited the highest value of $\mathrm{L}$ in all the evaluations conducted for bean seeds of the dark group (red and black), i.e., it was the lightest-colored genotype. The behavior of this genotype in regard to color was also differential when the combined mean value of the genotypes is observed (Table 3). While the black seed coat genotypes (FT Nobre and IAC Diplomata) gained lightness, i.e., became lighter colored with an increase in storage time, the genotype SER 16 exhibited the opposite behavior, in which the storage time increased darkening of the bean seeds, as can be seen in Table 3 .

In order to separate the genotypes with black and red seed coat from the carioca and brown types, decompose the effects of the interactions, and separately identify the best genotypes in each environment, GGE-Biplot analysis was carried out in regard to the carioca and brown type bean seed.

In relation to bean seed color at harvest and at 30 and 60 days of storage for the genotypes with carioca and brown seed coats, the formation of two sectors of correlation among the environments studied can be observed in Figures 5, 6, and 7; the environments of Campinas in the fall/winter, Campinas in the summer, Votuporanga in the fall/winter, and Votuporanga in the summer are clustered in one of the sectors. According to the polygon formed, the genotype BRS Agreste (8) prevailed with the highest lightness of the bean seed for these environments, both at harvest and after 30 and 60 days of storage (Figures 5, 6, and 7). The environments of Ribeirão Preto in the summer and Ribeirão Preto in the fall/winter proved to be correlated and clustered in the second sector both for seed coat color at harvest and after 30 and 60 days of storage (Figures 5, 6, and 7). Genotype 2 (IAC Imperador) exhibited the least lightness for these environments, taking a position in the second sector in all evaluation times. Furthermore, considering the environments of Ribeirão Preto in the summer and Ribeirão Preto in the fall/winter, the genotype SEA5 (3) exhibited the highest degree of bean seed darkening in all the storage times (Figures 5, 6, and 7). 


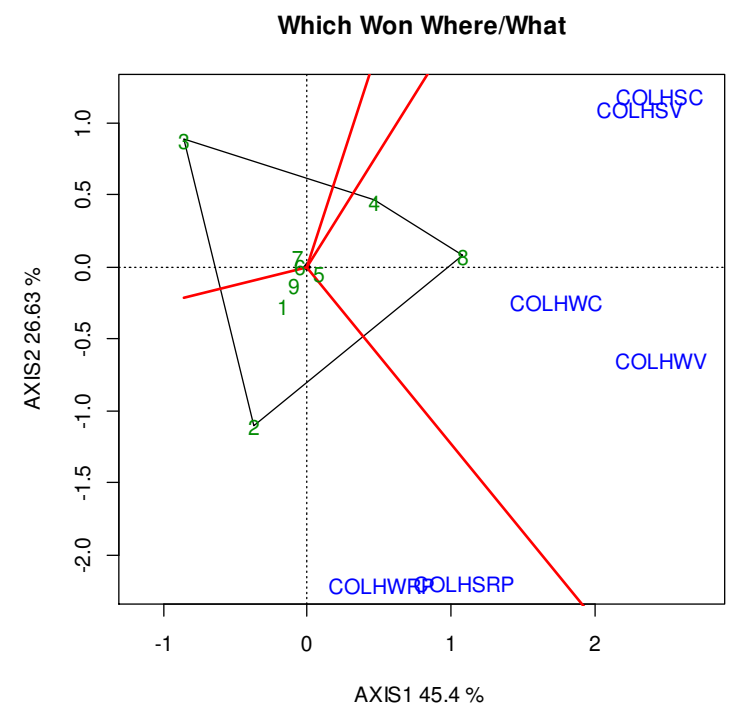

Figure 5. GGE-Biplot ("which won where") for the data of bean seed darkening after harvest (Lightness) of nine common dry bean genotypes, with seven of the carioca type and two of the brown (mulatinho) type; COLHIC = color at harvest in Campinas in the fall/winter; COLHIV = color at harvest in Votuporanga in the fall/winter; COLHIRP $=$ color at harvest in Ribeirão Preto in the fall/winter; COLHVC $=$ color at harvest in Campinas in the summer; COLHVV = color at harvest in Votuporanga in the summer; COLHVRP $=$ color at harvest in Ribeirão Preto in the summer. Genotypes: 1-Sea5, 2-IAC Imperador, 3- Pérola, 4-IAC Milênio, 5-BRS Estilo, 6-IAPAR 81, 7-IPR Tangará, 8-BRS Agreste, and 9-IAC Sintonia.

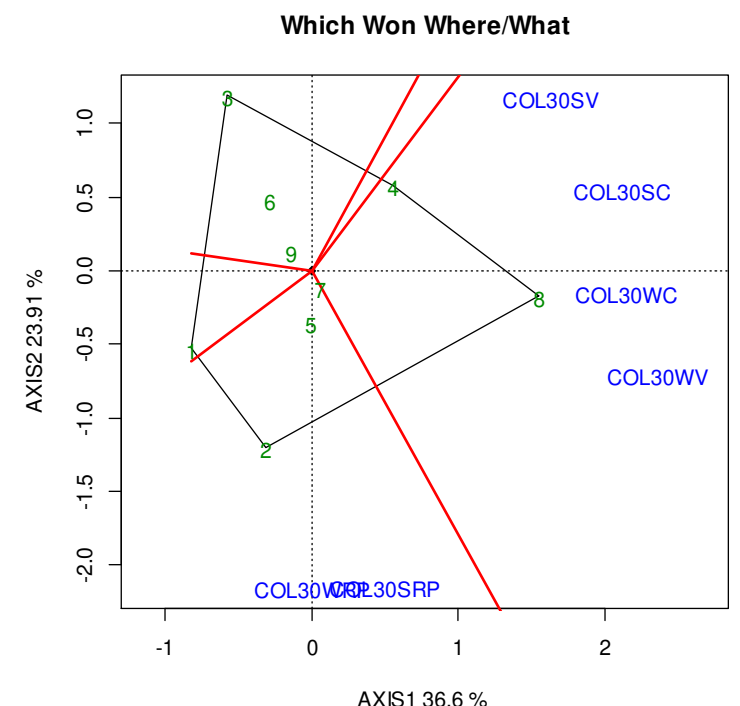

Figure 6. GGE-Biplot ("which won where") for the data of bean seed darkening with 30 days of storage (Lightness) of nine common dry bean genotypes, with seven of the carioca type and two of the brown (mulatinho) type; COL30WC $=$ color at 30 days in Campinas in the fall/winter; COL30WV $=$ color at 30 days in Votuporanga in the fall/winter; COL30WRP $=$ color at 30 days in Ribeirão Preto in the fall/winter; COL30SC $=$ color at 30 days in Campinas in the summer; COL30SV $=$ color at 30 days in Votuporanga in the summer; COL30SRP $=$ color at 30 days in Ribeirão Preto in the summer. Genotypes: 1-Sea5; 2-IAC Imperador; 3- Pérola; 4-IAC Milênio; 5-BRS Estilo; 6-IAPAR 81; 7-IPR Tangará; 8-BRS Agreste; and 9-IAC Sintonia. 


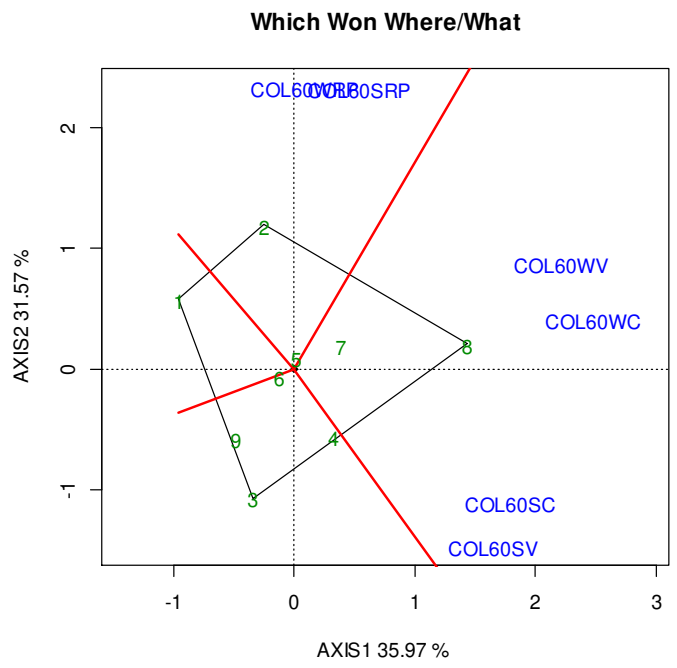

Figure 7. GGE-Biplot ("which won where") for the data of bean seed darkening with 60 days of storage (Lightness) of nine common dry bean genotypes, with seven of the carioca type and two of the brown (mulatinho) type; COL60WC $=$ color at 60 days in Campinas in the fall/winter; COL60WV $=$ color at 60 days in Votuporanga in the fall/winter; COL60WRP $=$ color at 60 days in Ribeirão Preto in the fall/winter; COL60SC $=$ color at 60 days in Campinas in the summer; COL60SV $=$ color at 60 days in Votuporanga in the summer; COL60SRP $=$ color at 60 days in Ribeirão Preto in the summer. Genotypes: 1-Sea5, 2-IAC Imperador, 3- Pérola, 4-IAC Milênio, 5-BRS Estilo, 6-IAPAR 81, 7-IPR Tangará, 8-BRS Agreste, and 9-IAC Sintonia.

Oliveira (2010) evaluated cooking time and bean seed darkening of five genotypes of the carioca and black group under storage environment conditions and under refrigeration for six months. Results showed that for the black group, the standard of lightness in color was maintained, without the occurrence of purplish bean seeds, i.e., without change in the color standard suitable for cultivars of this group, differing from the results found in the present study, in which the bean seeds with a black seed coat exhibited an increase in lightness of color over the storage period. Nevertheless, for the genotypes of the carioca group, Oliveira et al. (2011) identified an increase in darkening of the bean seed coat and in cooking time as a result of prolonged storage, corroborating the results of the present study.

\section{Relations among variables}

Knowledge of the relation among traits is of great interest in plant breeding because it allows evaluation of how much change in one trait can affect other traits. Thus, the relation between the variables studied was analyzed for the two crop seasons (fall/winter 2016 and summer 2016/2017), represented by the GGE-Biplot graph (Figures 8 and 9).

For the fall/winter crop season, there was no correlation between the variables in regard to bean seed color (COLH, COL30, and COL60) and the variables of bean seed cooking time (CTH, CT30, and CT60) (Figure 8). It is important to highlight that the growing conditions of the fall/winter crop season were more favorable, providing for greater plant health and less stress by high temperature, contributing to lighter-colored bean seeds since lightness of the seed coat can be affected by diseases as well as by high temperature in bean seed development.

In the summer, the period that most contributed to darkening of bean seeds, the variable of cooking time with the longest storage time, CT60, exhibited a relationship with the variables of bean seed color, especially COL60, indicating that at 60 days of storage, the lightness of bean 
seed color decreases, and the bean seed cooking time increases, which may be related to oxidation of the phenolic compounds due to the time in storage (Figure 9). Studies carried out by OLIVEIRA (2010) in five groups of dry bean indicated a high relation between darkening of the seed coat and cooking time, and significant increases were observed for these traits in accordance with storage time.

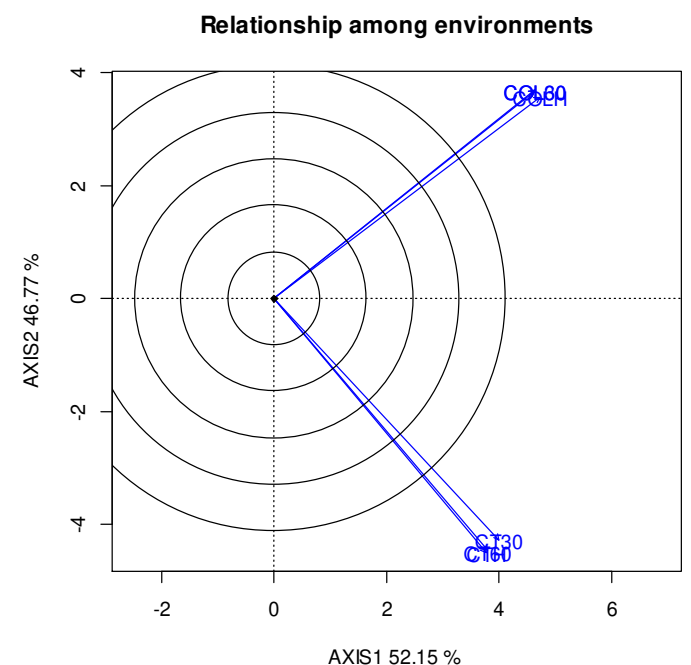

Figure 8. GGE-Biplot of the relation between variables for the six variables of fall/winter 2016 considering the three environments studied (Campinas, Votuporanga, and Ribeirão Preto); CTHW = cooking time at harvest; CT30W = cooking time after 30 days of storage; CT60W = cooking time after 60 days of storage; COLHW = color of the seed coat at harvest; COL30W = color of the seed coat after 30 days of storage, and COL60W $=$ color of the seed coat after 60 days of storage.

Relationship among environments

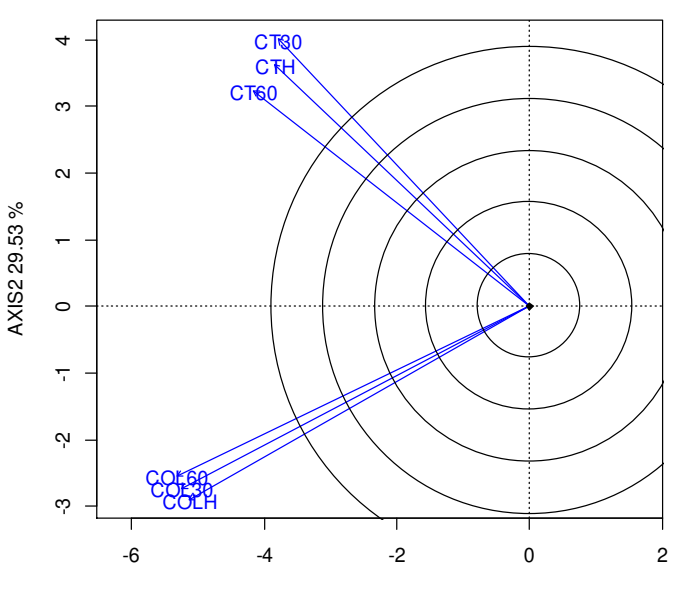

AXIS1 $61.28 \%$

Figure 9. GGE-Biplot of the relation between variables for the six variables of summer 2016/2017 considering the three environments studied (Campinas, Votuporanga, and Ribeirão Preto); CTHS = cooking time at harvest; $\mathrm{CT} 30 \mathrm{~S}=$ cooking time after 30 days of storage; $\mathrm{CT} 60 \mathrm{~S}=$ cooking time after 60 days of storage; COLHS = color of the seed coat at harvest; COL30S = color of the seed coat after 30 days of storage, and COL60S $=$ color of the seed coat after 60 days of storage.

Genetics and Molecular Research 20 (2): gmr18779

CFUNPEC-RP www.funpecrp.com.br 


\section{CONCLUSIONS}

The crop season affected only the variables of seed coat lightness in all the evaluations. Darker bean seeds were observed in the summer growing season. The Campinas, location with mild summer temperatures, exhibited bean seeds with greater lightness and shorter cooking time. There was no correlation between color and cooking time.

\section{ACKNOWLEDGMENTS}

The authors thanks CAPES - Coordenação de Aperfeiçoamento de Pessoal de Nível Superior and FAPESP - Fundação de Amparo à Pesquisa do Estado de São Paulo for financial support.

\section{CONFLICTS OF INTEREST}

The authors declare no conflict of interest.

\section{REFERENCES}

Bassinello PZ, Cobucci RMA, Ulhôa VG, Melo LC, et al. (2003). Aceitabilidade de três cultivares de feijoeiro comum. Comunicado técnico 66. Embrapa Arroz e Feijão, Santo Antônio de Goiás.

Bertoldo JG, Coimbra JLM, Guidolin AF and Rocha F (2009). Tempo de cocção de grãos de feijão em função de doses de fósforo no plantio e do tempo de armazenamento. Biotemas. 22 (1): 39-47.

Carbonell SAM, Carvalho RL and Pereira VR (2003). Qualidade tecnológica de grãos de genótipos de feijoeiro cultivados em diferentes ambientes. Bragantia. 62(3): 369-379.

Cargnelutti Filho A, Ribeiro ND and Jost E (2006). Número necessário de experimentos para a comparação de cultivares de feijão. Cienc Rural. 36(6): 1701-1709.

Custódio CC, Viva MR, Nunes RCA and Agostini EAT (2009). Tolerância cruzada induzida por choque térmico na germinação de semente de feijão. Rev. Bras. Sementes. 31(1): 131-143.

Dalla Corte A, Moda-Cirino V, Scholz MBS and Destro D (2003). Environment effect on grain quality in early common bean cultivars and lines. Crop Breed Appl. Biotechnol. 3: 193-202.

Hohlberg AI and Stanley DW (1987). Hard-to-cook defect in black beans: protein and starch considerations. J. Agric. Food Chem. 1(35): 571-576.

Hosfield GL, Wassami NN and Uebersax MA (1990). Inheritance of physico-chemical seed characters related to culinary quality in dry bean. J. Am. Soc. Hortic. Sci. 115: 492-499.

Junk-Knievel DC, Vandenberg A and Bett KE (2007). An accelerated post-harvest seed coat darkening protocol for pinto beans grown across different environments. Crop Sci. 47: 694-702.

Mesquita RF, Corrêa DA, Abreu PMC, Lima ZAR, et al. (2007). Linhagens de feijão (Phaseolus vulgaris, L.): Composição química e digestibilidade protéica. Ciênc Agrotecnol. 31(4): 1114-1121.

Morais PPP, Valentini G, Guidolin AF, Baldissera JNC, et al. (2010). Influência do período e das condições de armazenamento de feijão no tempo de cocção. Ver. Ciênc. Agronôm. 41(4): 593-598.

Oliveira DP (2010). Qualidade tecnológica em grãos de feijão-comum em função de cultivares e condições de armazenamento. 2010. 95 p. Master's thesis. Universidade Federal de Lavras, Lavras-MG.

Oliveira, VR, Ribeiro ND, Maziero SM, Cargnelutti Filho A, et al. (2011). Qualidade para o cozimento e composição nutricional de genótipos de feijão com e sem armazenamento sob refrigeração. Ciênc. Rural. 41(5): 746-752.

Proctor JR and Watts BM (1987). Development of a modified Mattson bean cooker procedure based on sensory panel cookability evaluation. Canadian Institute of Food Science and Technology Journal, Apple Hill, 20(1): 9-14.

Ribeiro ND, Domingues LS, Gruhn EM, Zemolin AEM, et al. (2014). Desempenho agronômico e qualidade de cozimento de linhagens de feijão de grãos especiais. Rev. Ciênc. Agronôm. 45(1): 92-100.

Ribeiro ND, Rodrigues JA, Cargnelutti Filho A, Poersch NL, et al. (2007). Efeito de períodos de semeadura e das condições de armazenamento sobre a qualidade de grãos de feijão para o cozimento. Bragantia. 66(1): 157-163.

Ribeiro ND, Jost E and Cargnelutti Filho A (2004). Efeitos da interação genótipo x ambiente no ciclo e na coloração do tegumento dos grãos do feijoeiro comum. Bragantia. 63(3): 373-380. 
Rios AO, Abreu CMP and Corrêa AD (2002). Efeitos da época de colheita e do tempo de armazenamento no escurecimento do tegumento do feijão (Phaseolus vulgaris, L.). Ciênc. Agrotec. 26(3): 550-558.

Rodrigues JA, Ribeiro ND, Cargnelutti Filho A, Trentin M, et al. (2005). Qualidade para o cozimento de grãos de feijão obtidos em diferentes épocas de semeadura. Bragantia. 64(3): 369-376.

Scholz MBS and Fonseca Júnior NS (1999). Efeito de ambientes, dos genótipos e da interação genótipos x ambientes na qualidade tecnológica de feijão do grupo de cores no Estado do Paraná. In: Reunião Nacional de Pesquisa do Feijão, 6., 1999, Goiânia. Proceedings. Goiânia: Embrapa, p. 339-342.

Sgarbieri VC (1987). Alimentação e nutrição: fator de saúde e desenvolvimento. 1. ed. Campinas: Unicamp. 387 p.

Silva DA, Pinto-Maglio CAF, Oliveira EC, Reis RLM, et al. (2020). Influence of high temperature on the reproductive biology of dry edible bean (Phaseolus vulgaris L.) Sci. Agric. 77(3): e20180233.

Silva DA, Reis RLM, Gonçalves JGR, Carbonell SAM, et al. (2018). Effect of heat stress on common bean under natural growing conditions in three locations in different climate zones in the state of São Paulo. J. Plant Breed. Crop Sci. 10(6): 134-145.

Yan W, Hunt LA, Sheng Q and Szlavnics Z (2000). Cultivar Evaluation and Mega-Environment Investigation Based on the GGE Biplot. Crop Sci. 40(3): 597-605. https://doi.org/10.2135/cropsci2000.403597x. 